\title{
TAMAN MINI INDONESIA INDAH: EDUCATION OR ENTERTAINMENT?
}

\author{
Anak Agung Ayu Wulandari \\ Interior Design Department, School of Design, BINUS University \\ Jln. KH. Syahdan No.9, Palmerah, Jakarta Barat 11480 \\ ayuwulan.indrajaya@gmail.com
}

\begin{abstract}
With combination of attractive appearance, taste, smell and sound, open air-museums can offer so many things to visitors; from educate to educate and entertain. Here, 'edutainment' concept starts to take place. The problem is there can be misconception between the creators and visitor's perception. In this research, qualitative methodology, through interviews to get information form creator's perspective and visitor survey to get information form the visitors' perspectives were conducted with Taman Mini Indonesia Indah as the case study. The findings show that there is still misconception about education and entertainment perceptions in Taman Mini. Taman Mini has strong educational purposes, but because of ack of attractive educational programs, lack of information and interpretation and no encouragement to participate in the educational programmes, visitors considered their visits as recreational, rather than educational. In relation with postmodern phenomenon, Taman Mini can be considered as postmodern and adopting 'edutainment' concept, but this concept has became blur and vague, thus Taman Mini now only famous as a recreation venue.
\end{abstract}

Keywords: Taman Mini Indonesia Indah, Open-air Museums, Edutainment

\begin{abstract}
ABSTRAK
Dengan kombinasi dari penampilan yang menarik, rasa, bau dan suara, museum terbuka dapat menawarkan berbagai hal kepada pengunjung, mulai dari edukasi sampai dengan edukasi dan hiburan. Disini konsep 'edutainment' mulai mengambil alih. Permasalahan yang muncul adalah kemungkinan terjadinya perbedaan persepsi antara pendiri dan pengunjung. Pada penelitian ini metode kualitatif digunakan, melalui wawancara untuk mengumpulkan data dari sudut pandang pendiri dan survey pengunjung untuk mendapatkan data dari sudut pandang pengunjung dengan Taman Mini Indonesia Indah sebagai studi kasus. Hasilnya menunjukan bahwa masih terjadi perbedaan persepsi mengenai pendidikan dan hiburan di Taman Mini. Taman Mini memiliki tujuan pendidikan yang sangat kuat, namun karena kurangnya program-program pendidikan yang menarik, kurangnya informasi dan intepretasi serta tidak adanya dorongan untuk berpartisipasi dalam program-program edukasi, pengunjung menggagap kunjungan mereka sebagai rekreasi semata. Dalam kaitannya dengan fenomena postmodern, Taman Mini dapat dianggap sebagai postmodern dan mengadopsi konsep 'edutainment', namun konsep ini menjadi kabur dan sekarang hanya terkenal sebagai tempat rekreasi.
\end{abstract}

Kata kunci: Taman Mini Indonesia Indah, Museum terbuka, Edutainment 


\section{PENDAHULUAN}

Banyak cara untuk mendidik dan memperluas wawasan seseorang. Salah satu cara yang paling mudah dan menyenangkan adalah dengan mengunjungi museum, dimana di dalam sebuah museum seseorang dapat mempelajari bahkan ikut merasakan pengetahuan melalui cara-cara yang unik dan efektif. Seperti dikemukakan oleh Hooper-Greenhill (1994) bahwa pendidikan adalah salah satu fungsi museum, dan merupakan alasan utama dari keberadaan sebuah museum. Pada waktu lalu, pendidikan dalam museum hanya ditujukan untuk anak-anak usia sekolah, tetapi saat ini pendidikan dalam museum harus mencapai kalangan yang lebih luas, mulai dari usia sekolah, dewasa bahkan sampai kalangan usia lanjut yang sering disebut dengan pendidikan tanpa batas usia atau life-long learning. Lebih lanjut dijelaskan bahwa peran pendidikan sebuah museum dapat dicapai melalui dua cara, yaitu pameran-yang dijabarkan sebagai bentuk dari komunikasi massa, dan program-program edukasi sebagai bentuk dari komunikasi interpersonal.

Dahulu peran pendidikan di museum hanya terbatas pada pameran. Pada model ini pesanpesan dan informasi bersifat satu arah, dipersiapkan oleh pihak museum dan diarahkan kepada pengunjung. Dalam teori komunikasi ini tidak ada interaksi antara pengunjung dengan pameran ataupun benda-benda pamer lainnya. Pengunjung sebagai penonton pasif hanya dapat melihat bendabenda pamer melalui kaca-kaca berdebu. Walaupun sebenarnya para pengunjung mempunyai karakteristik dan pendapat yang berbeda terhadap apa yang ingin dilihat atau apa yang tidak ingin dilihat, mereka hanya mempunyai satu pilihan yaitu melihat apa yang sudah dipersiapkan oleh para kurator museum yang sering disebut sebagai curatorial 'hypodemics' (Hooper-Greenhill, 1994:3). Inilah sebabnya mengapa museum-museum pada masa lampau gagal untuk berkomunikasi. Namun, dalam 20-30 tahun terakhir, teori komunikasi massa mulai ditolak dan digantikan oleh sebuah konsep baru yang mengarah kepada model komunikasi interpersonal, dimana pengunjung diajak untuk lebih aktif. Komunikasi interpersonal ini dapat berbentuk percakapan langsung antara dua orang atau beberapa orang dalam satu kelompok, contohnya adalah sesi-sesi pendidikan yang dewasa ini banyak diselenggarakan di museum, dimana komunikasi interaktif dan dua arah terjadi. Pada museummuseum masa kini, peran pendidikan menjadi lebih fleksibel dan lebih bervariasi. Mereka mengadopsi kedua bentuk komunikasi, komunikasi massa melalui pameran dan komunikasi interpersonal melalui program-program pendidikan. Urry (2002) menyebutkan museum jenis ini adalah museum postmodern, dimana pengunjung tidak lagi diharapkan untuk berdiri tegak mengagumi sebuah benda pamer, tetapi juga untuk berpartisipasi aktif dalam sebuah pameran.

Selain melalui program-program pendidikan, komunikasi interpersonal juga dilakukan dengan berbagai media, seperti multimedia, layar sentuh, audio visual ataupun intepretasi hidup/nyata (living interpretation). Hal ini tidak hanya membuat museum menjadi lebih menarik, tetapi juga menambahkan nilai-nilai hiburan (entertainment) dalam sebuah museum postmodern. Fenomena postmodern dimana pendidikan dikombinasikan dengan hiburan dalam sebuah museum, baik museum terbuka maupun tertutup atau fasilitas rekreasi lainnya berkembang di seluruh belahan dunia. Di dalam fasilitas ini tidak ada batasan yang jelas dan tegas antara konsep pendidikan dan hiburan. Kedua konsep ini seperti melebur menjadi suatu konsep baru 'edutainment, dengan definisi sebagai berikut, 'events, programs and attractions where the entertainment qualities are the primary draw, with the learning or education being a by product... It consists of two equally important parts: the format (entertainment) and the message/content (education)' (White, 2003: 2). Konsep ini adalah cara baru untuk mendidik publik dengan cara-cara yang lebih menyenangkan, sehingga sering kali mereka tidak sadar kalau mereka sedang belajar.

Namun tetaplah harus diingat bahwa sebanyak atau seberagam apapun media atau fasilitas yang ditawarkan, sebagai museum fungsi pendidikan tetaplah merupakan fungsi utama dan tidak tergantikan. Boardman (1997) mengatakan, bila berhubungan dengan masalah otentisitas, kebenaran 
dan filosofi, banyak museum konvensional yang mempertanyakan kelayakan dalam mengadopsi konsep edutainment. Oleh karena itu, bentuk-bentuk komunikasi massa masih dipercaya sebagai satusatunya cara untuk mendidik, menjaga dan melestarikan benda-benda bersejarah di dalam sebuah museum. Hendry (2000) menyatakan bahwa memang perbedaan antara pendidikan dan hiburan dalam konteks museum di negara-negara barat sangatlah jelas. Pendidikan terpisahkan dari hiburan. Museum didirikan untuk fungsi pendidikan, untuk mengumpulkan, mempelajari dan melestarikan benda-benda bersejarah, seperti contohnya Ashmolean Museum di Oxford, yang menjadi pusat dari penelitian sains dan British Museum, sebagai museum pertama yang sangat kuat diasosiasikan dengan pendidikan. Tidak hanya itu, pada museum terbuka dimana sejarah yang dihidupkan kembali (living history) ditawarkan, lengkap dengan berbagai fasilitas seperti panggung terbuka/tertutup, kafe, restauran dan toko suvenir, pendidikan masih tetap memegang fungsi utama. Skansen misalnya, didirikan pada tahun 1891 oleh Arthur Hazelius sebagai museum terbuka pertama yang ditujukan untuk pendidikan (Hitchcock, et al, 1997). Buku panduannya memberikan penjelasan lengkap mengenai alasan beberapa bangunannya merupakan duplikat dan bukan bangunan asli (Hendry, 2000) yang berarti bahwa Hazelius mendirikan Skansen memang untuk pendidikan. Pada tahun 1892 dibangun kafe, pada tahun 1952 ditambahkan sebuah restoran dan panggung terbuka didirikan pada tahun 1911 untuk berbagai pertunjukan gerak dan lagu. Hal ini menandakan bahwa selain untuk tujuan pendidikan Skansen juga memiliki tujuan rekreasi. Walaupun museum terbuka memiliki potensi yang sangat bagus dalam mengadopsi konsep edutainment dibandingkan museum tertutup, namun ini tidak berlaku di Skansen, karena kafe, restauran dan toko suvenir yang ada hanyalah merupakan fasilitas pelengkap, dan fasilitas-fasilitas utama mereka adalah fasilitas yang memegang peran pendidikan.

Apabila museum terbuka di negara barat sangat konsisten dengan peran pendidikan mereka, lain halnya dengan museum terbuka di negara-negara Asia. Museum terbuka di Asia, walaupun menampilkan satu hal yang sama yaitu budaya, muncul dengan berbagai model dan karakteristik, sehingga penulis dan peneliti memberi mereka nama-nama yang berbeda, seperti Taman Mini Indonesia Indah di Jakarta yang dapat dikategorikan sebagai museum terbuka atau Open-air Museums (Hitchcock, 1998). Splendid China, Window of the World di China, Polynesian Cultural Centre (PCC) di Hawaii, Tawian Aboriginal Culture Park (TACP) dan Formosan Aboriginal Cultural Village (FACV) di Tawian sering disebut sebagai Ethnographic Theme Parks (Stanley, 1998) dan beberapa museum terbuka di Jepang yang mengadopsi tema-tema barat dikenal sebagai Theme Parks (Hendry, 2000).

Bagaimanakah museum terbuka dengan berbagai sebutan ini mengadopsi konsep edutainment? Apakah tetap konsisten dengan tujuan pendidikan seperti museum terbuka di barat ataukah lebih mengarah kepada rekreasi dan hiburan (entertainment), sehingga beberapa museum bahkan memiliki sebutan Theme Parks? Keunikan dari museum terbuka Asia atau yang sering juga disebut dengan taman budaya (Cultural Park) adalah mereka dapat menawarkan pendidikan sekaligus hiburan, sehingga fungsi pendidikan dapat dikemas dengan cara yang unik pula. Penampilan objekobjek budaya (entah asli atau replika) dalam sebuah ruang pamer atau museum adalah salah satu cara yang paling mudah dan umum digunakan, selain itu juga dapat dilakukan dengan intepretasi nyata/hidup (living interpretation) melalui pertunjukan-pertunjukan budaya. Namun pertanyaan berikutnya adalah, apabila museum terbuka atau taman budaya tersebut sudah dipersiapkan sedemikian rupa oleh para pendiri dan manajemen dengan menekankan nilai-nilai pendidikan tetapi dikemas dengan cara yang menghibur, apakah pesan-pesan pendidikan yang ingin disampaikan akan dapat diterima dengan baik oleh pengunjung ataukah pengunjung akan menganggap kunjungan mereka sebagai kunjungan rekreasi semata? Karena inilah yang terjadi di taman-taman budaya Jepang (Hendry, 2000). Pengunjung tidak pernah menganggap kunjungan mereka sebagai kunjungan edukasi walaupun mereka melihat pertunjukan budaya dan objek-objek budaya di dalam sebuah bangunan museum, mereka hanya menganggap kunjungan mereka sebagai kunjungan rekreasional tanpa adanya nilai-nilai pendidikan sedikitpun. 
Untuk meneliti hal ini lebih jauh, salah satu museum terbuka di Jakarta yaitu Taman Mini Indonesia Indah (Taman Mini) akan digunakan sebagai studi kasus. Apakah sebenarnya tujuan dari Taman Mini itu sendiri. Apakah Taman Mini termasuk salah satu museum terbuka yang sudah mengadopsi konsep edutainment dan pertanyaan yang paling penting adalah bagaimanakah persepsi pendiri dan manajemen terhadap nilai pendidikan dan rekreasi di Taman Mini dan bagaimanakah persepsi dari pengunjung Taman Mini. Apakah seperti taman budaya di Jepang, dimana kedua persepsi ini berbeda atau manajemen dan pengunjung sudah memiliki persepsi yang sama.

\section{METODE PENELITIAN}

Penelitian dilakukan dengan menggunakan metode kualitatif. Untuk mendapatkan data mengenai mengenai persepsi manajemen dan persepsi pengunjung terhadap nilai pendidikan dan rekreasi di Taman Mini dilakukan metode pengumpulan data secara bertahap. Tahap pertama adalah pengumpulan data sekunder melalui berbagai sumber seperti buku, jurnal artikel, sumber-sumber online, koran serta laporan penelitian lainnya yang pernah dilakukan mengenai Taman Mini, museum terbuka, taman budaya, dan pendidikan serta hiburan dalam konteks museum.

Tahap berikutnya adalah pengumpulan data primer. Karena penelitian ditujukan untuk mendapatkan pengertian dari dua perspektif, yaitu perspektif manajemen Taman Mini dan perspektif pengunjung, maka untuk memperoleh hasil yang maksimal digunakan kombinasi dari kedua metode pengumpulan data; kualitatif dan kuantitatif atau 'methodological triangulation' (Easterby-Smith, Thorpe dan Lowe, 1991: 134). Data kualitatif dikumpulkan melalui wawancara terstruktur dan mendalam dengan kepala divisi pendidikan dan kepala divisi pemasaran dan public relations Taman Mini untuk mendapatkan pengertian mendalam mengenai konsep pendirian Taman Mini, visi dan misinya serta nilai-nilai pendidikan dan hiburan yang ada di Taman Mini. Sedangkan data kuantitatif diperoleh dengan survei pengunjung melalui penyebaran kuesioner. Kuesioner sebagai salah satu cara untuk mengumpulkan informasi mengenai sikap, persepsi dan pengertian dari sebuah populasi (dalam hal ini pengunjung Taman Mini dianggap sebagai populasi) dianggap lebih mudah dan lebih hemat waktu dibandingkan dengan melakukan wawancara pengunjung satu per satu. Kuesioner yang digunakan dalam penelitian ini tediri dari 4 bagian dan merupakan kombinasi dari skala penilaian, skala likert, dan pilihan ganda. Bagian pertama mengenai karakteristik responden, termasuk di antaranya adalah umur, jenis kelamin, pekerjaan, tempat tinggal dan lain-lain. Bagian kedua untuk mengetahui tujuan responden mengunjungi Taman Mini, bagian ketiga untuk mengetahui kegiatan, fasilitas apa sajakah yang dikunjungi, apa yang mereka lakukan di sana, dan lain-lain serta bagian keempat merupakan survei sikap. Secara keseluruhan hanya diperlukan kurang dari 15 menit untuk menjawab semua pertanyaan. Survei dilakukan menggunakan Convience Sampling Method (Clark, et.al, 1998), dimana sampel dipilih secara acak, yaitu pengunjung yang sedang berada di area Taman Mini pada waktu terbaik dimana mereka tidak sedang tergesa-gesa melakukan suatu aktivitas atau sedang menuju ke fasilitas tertentu. Metode ini biasanya digunakan pada saat melakukan wawancara di area pantai atau sedang piknik dimana responden sedang duduk diam dan pewawancara yang bergerak (Veal, 1997: 12).

Setelah tahap pengumpulan data selesai dilakukan, tahap berikutnya adalah analisis data yang dilakukan menggunakan General Analytic Procedure (Hussey and Hussey, 1994: 257) untuk data kualitatif, sedangkan data kuantitatif dianalisis menggunakan SPSS. Dalam penelitian ini kedua metode pengumpulan data digunakan untuk mendapatkan data dari dua perspektif, bukanlah untuk memverifikasi validitas data dari satu perspektif terhadap perspektif lainnya, tetapi untuk meningkatkan keakuratan data dari keseluruhan analisis dengan memperoleh data dari kedua perspektif, manajemen Taman Mini dan pengunjung dan menghubungkan kedua data tersebut (Mason, 1994). 


\section{HASIL DAN PEMBAHASAN}

\section{Persepsi Pendiri dan Manajemen Taman Mini}

Hasil wawancara dengan kedua kepala divisi Taman Mini dibagi menjadi 4 bagian; bagian pertama mengenai Tama Mini secara umum, seperti filosofi dan dasar-dasar pendirian, visi dan misi serta sejarah Taman Mini. Bagian kedua mengenai Manajemen dan strategi marketing Taman Mini, bagian ketiga mengenai data pengunjung Taman Mini, seperti jumlah pengunjung, profil pengunjung dan bagian terakhir mengenai program-program edukasi dan acara-acara lain yang diselenggarakan oleh Taman Mini.

Dari kedua wawancara tidak didapatkan sejarah mengenai pendirian Taman Mini, namun informasi tersebut tertulis lengkap dalam buku panduan Taman Mini. Pengerjaan Taman Mini dimulai pada tahun 1971. Empat tahun kemudian, pada tahun 1975, Taman Mini Indonesia Indah dibuka untuk pertama kalinya, dibangun di lahan seluas 425 are, sebuah danau buatan dengan miniatur dari kepulauan Indonesia menjadi pusat dari Taman Mini, mengelilingi danau, 27 anjungan daerah didirikan untuk menampilkan 27 propinsi yang ada di Indonesia. Namun saat ini Taman Mini telah mengubah salah satu anjungan, yaitu anjungan Timor Timur menjadi Museum Timor Timur dan menambahkan jumlah anjungan daerah, sesuai dengan perubahan jumlah propinsi di Indonesia. Di dalam anjungan, dapat ditemukan berbagai informasi mengenai propinsi tersebut, dalam bentuk manekin dengan busana tradisional, artefak-artefak budaya, cinderamata dan lain-lain. Selain anjungan daerah, juga terdapat berbagai tempat ibadah, ruang serba guna, taman burung, taman bunga, aquarium, teater IMAX, istana anak-anak dan 20 museum.

Buku panduan Taman Mini Indonesia Indah (1996) menyebutkan mengenai filosofi didirikannya Taman Mini, yaitu untuk mencapai keseimbangan antara pembangunan fisik dan ekonomi dengan pembangunan mental dan spiritual. Ketika itu di Indonesia sedang terjadi pembangunan fisik dan ekonomi secara besar-besaran. Ibu Negara pada saat itu, Ibu Tien Soeharto berpikir bahwa pembangunan fisik dan mental tidak akan lengkap tanpa diikuti dengan pembangunan mental dan spiritual dari manusia Indonesia. Berdasarkan filosofi ini, Ibu Tien mengeluarkan gagasan untuk membangun sebuah taman yang menggambarkan keindahan dan kebesaran Indonesia dalam bentuk miniatur dengan tujuan untuk meningkatkan nasionalisme dan rasa cinta tanah air. Beliau berharap dengan mendirikan taman ini, masyarakat Indonesia akan belajar lebih dalam mengenai keanekaragaman budaya dan akan meningkatkan kebanggaan sebagai bangsa Indonesia, atau dengan kata lain, bangsa Indonesia tidak hanya akan berkembang secara fisik, namun juga secara mental dan spiritual. Lebih lanjut, visi ini dijabarkan ke dalam beberapa misi, yaitu: a) membangun dan meningkatkan rasa nasionalisme; b) meningkatkan persatuan antar berbagai suku bangsa dan agama; c) meningkatkan apresiasi budaya; d) memperkenalkan kebudayaan tradisional; mendorong wisatawan domestik dan internasional; e) menyediakan fasilitas rekreasi yang juga memiliki nilai-nilai edukasi.

Mengenai kebijakan pendidikan, kepala divisi pendidikan Taman Mini mengatakan bahwa Taman Mini tidak memiliki kebijakan pendidikan tertentu. Memang ada beberapa petunjuk untuk anjungan daerah, museum dan taman-taman dalam melaksanakan peran edukasi mereka, namun tidak semua fasilitas ini mengikuti petunjuk tersebut. Karena fasilitas ini memiliki manajemen yang berbeda-beda; anjungan daerah dikelola oleh masing-masing pemerintah propinsi, museum dikelola oleh kementrian, sedangkan museum dan taman lainnya, seperti Museum Indonesia, Taman Bunga, Taman Burung dan sebagainya mempunyai manajemen dan direktur masing-masing sehingga segala hal mengenai pendidikan diserahkan sepenuhnya kepada pemerintah daerah ataupun kementerian terkait, jika mereka ingin melaksanakan sesuai peraturan tersebut, tetapi lebih penting lagi jika mereka menyediakan dana untuk pelaksaan pameran dan program-program edukasi atau tidak. 
Selain mengenai seni dan budaya tradisional Indonesia, pendidikan di Taman Mini juga ditekankan kepada lingkungan alam Indonesia, seperti tanaman dan hewan khas Indonesia. Pendidikan ini biasanya dilaksanakan oleh anjungan melalui pelatihan-pelatihan seperti pelatihan seni tari tradisional dan teater. Di Istana Anak-anak juga tersedia berbagai pelatihan untuk anak-anak seperti musik dan wayang. Sementara pendidikan yang berhubungan dengan lingkungan alam Indonesia diselenggarakan oleh Aquarium, Museum Serangga, Taman Burung melalui kolam sentuh, video dan lain sebagainya. Di dalam museum juga tersedia program-program pendidikan seperti bagaimana cara membuat kerajinan tradisional dan bagaimana cara melestarikan objek. Namun peran pendidikan di Taman Mini lebih diutamakan kepada pengunjung dalam kalangan pelajar. Selain grup sekolah yang berasal dari seluruh Indonesia, Taman Mini juga membantu pelajar dalam melakukan penelitian dan kerja praktik.

Berdasarkan pernyataan dari buku panduan Taman Mini, dapat disimpulkan bahwa Taman Mini didirikan dengan visi mendidik dan memperluas wawasan dan pengetahuan Bangsa Indonesia mengenai keanekaragaman budaya Indonesia sehingga dapat meningkatkan kesadaran nasional dan rasa cinta terhadap nusa dan bangsa. Sangat jelas terlihat bahwa Taman Mini mempunyai misi pendidikan yang sangat kuat. Kedua kepala divisi Taman Minipun memberikan pernyataan yang serupa, hanya saja kepala divisi marketing \& PR Taman Mini menambahkan bahwa pencapaian misi ini tidak dapat dilakukan secara instan, tetapi diperlukan suatu proses dan di Taman Mini prosesnya adalah pertama-tama dengan memperkenalkan kebudayaan tradisional, kedua meningkatkan apresiasi masyarakat terhadap kebudayaan tradisional, dan ketiga melalui pelajaran. Dengan adanya proses ini diharapkan cinta terhadap kebudayaan Indonesia akan tumbuh dan akhirnya meningkatkan rasa nasionalisme dan cinta tanah air.

Dari penjelasan ini dapat disimpulkan bahwa Taman Mini tidak berusaha untuk mendidik dengan cara memaksa, tetapi melalui sebuah proses pembelajaran. Melalui berbagai fasilitas dan pameran, pengunjung memiliki kebebasan utnuk memilih yang ingin mereka lihat dan fasilitas apa yang ingin mereka kunjungi, apakah anjungan daerah, taman-taman ataupun museum. Namun di dalam fasilitas-fasilitas tersebut, Taman Mini mengadopsi bentuk komunikasi masa dalam melaksanakan peran edukasi mereka (Hooper-Greenhill, 1994), dimana pengunjung menerima secara pasif semua pesan-pesan yang disampaikan. Walaupun Taman Mini juga mengambil bentuk komunikasi interpersonal, tetapi bentuk ini terbatas pada pengunjung dari kalangan pelajar atau kalangan tertentu saja yang ikut serta dalam program-program pelatihan seni tradisioinal atau pelatihan lainnya. Ketika ditanyakan apakah Taman Mini sudah mencapai tujuan utamanya, kedua responden mengatakan bahwa tujuan tersebut belum tercapai bahkan masih sangat jauh untuk dicapai. Untuk mengatasi masalah ini, Taman Mini mencoba untuk memberikan suasana rekreasi kepada pengunjungnya. Melalui suasana rekreasi, diharapkan para pengunjung lebih tertarik untuk mempelajari kebudayaan tradision, mendapatkan wawasan baru dan memperkaya diri mereka.

\section{Persepsi Pengunjung}

Hasil survei pengunjung dibagi menjadi 4 bagian yang mewakili keempat bagian kuesioner. Bagian pertama mengenai profil dari pengunjung, bagian kedua mengenai tujuan mereka mengunjungi Taman Mini, ketiga mengenai fasilitas-fasilitas apa saja yang digunakan dan terakhir mengenai sikap mereka terhadap Taman Mini. Dari 148 responden, terdapat 3 sampel eror dengan profil sebagai berikut; $46.9 \%$ merupakan responden pria dan 53.1\% wanita. Responden didominasi oleh responden yang berasal dari berbagai daerah di Indonesia yaitu sebanyak 96.9\% dan hanya 3.4\% responden yang berasal dari luar negeri atau merupakan wisatawan mancanegara. Untuk kategori usia didominasi oleh usia 17-25 tahun sebanyak $28.97 \%$ dan 8-16 tahun sebanyak $21.38 \%$, diikuti oleh responden yang berusia 26-34 tahun (20\%), 36-43 tahun (15.86\%), diatas 43 tahun(12.41\%) dan di bawah 8 tahun (1.38\%). Dari angka ini terlihat jelas bahwa pengunjung Taman Mini didominasi oleh pelajar atau pengunjung usia sekolah. Sedangkan dilihat dari latar belakang pendidikan, sebagian besar responden merupakan lulusan universitas sebanyak 45.52\%, diikuti dengan SMU (30.43\%), SD (14.48\%) dan 
SMP (9.66\%). Responden yang bekerja di sektor swasta adalah yang terbesar sebanyak 44.83\%, diikuti oleh pelajar (37,93\%), lainnya (8.97\%), PNS (7.59\%) dan TNI (0.69\%). Responden yang terbesar menganut agama Islam sebanyak 44.83\%, diikuti oleh Kristen Protestan (10.34\%), Hindu (8.28\%), Katholik (2.76\%) dan Buddha (1.38\%).

Bagian kedua dari kuesioner mengenai tujuan mereka mengunjungi Taman Mini. Dari hasil wawancara, kedua kepala divisi Taman Mini sudah menyebutkan bahwa secara umum pengunjung Taman Mini datang dengan tujuan rekreasi dan hasil kuesioner mendukung pernyataan tersebut. Ketika ditanyakan alasan berkunjung, 52.41\% responden menyatakan bahwa tujuan mereka adalah untuk berlibur dan rekreasi. Sedangkan tujuan belajar hanya $12.41 \%$ dan $11.72 \%$, dari survei sikap 51.72\% responden setuju dan 38.62\% responden sangat setuju bahwa Taman Mini lebih baik digunakan sebagai tempat rekreasi.

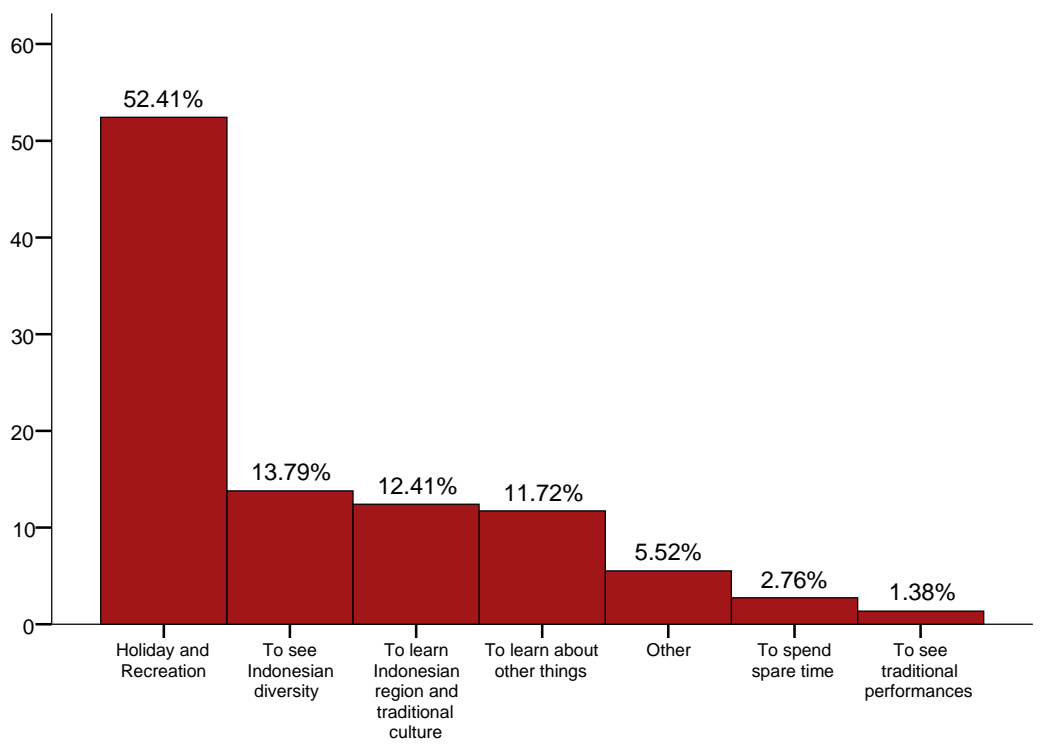

Gambar 1 Alasan Responden Mengunjungi Taman Mini

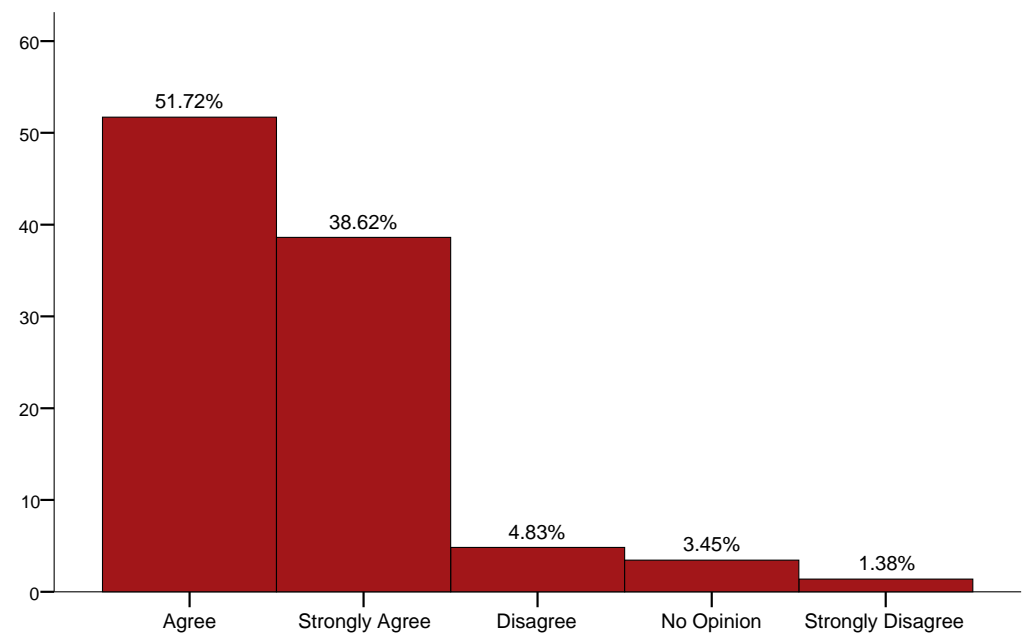

Gambar 2 Sikap Responden terhadap Anggapan bahwa Taman Mini Sebagai Tempat Rekreasi 
Hasil lain juga menunjukan bahwa 64.14\% responden menggangap Taman Mini sebagai taman rekreasi dan bukan museum terbuka. Hal ini mengilustrasikan bahwa pengunjung memiliki orientasi rekreasi. Ini juga terlihat dari hasil lainnya dimana hampir semua responden $(91.72 \%)$ mengunjungi anjungan daerah, tetapi hanya $60 \%$ responden yang mengunjungi museum. Tidak menutup kemungkinan responden mengunjungi ketiga fasilitas ini pada hari yang sama. Dibandingkan dengan anjungan dan taman, museum dianggap memiliki nilai pendidikan yang lebih tinggi. Dan karena kebanyakan pengunjung memiliki orientas rekreasi, untuk bersantai dan menghabiskan waktu bersama keluarga mereka, hal ini memperkecil kemungkinan mereka untuk mengunjungi museum.

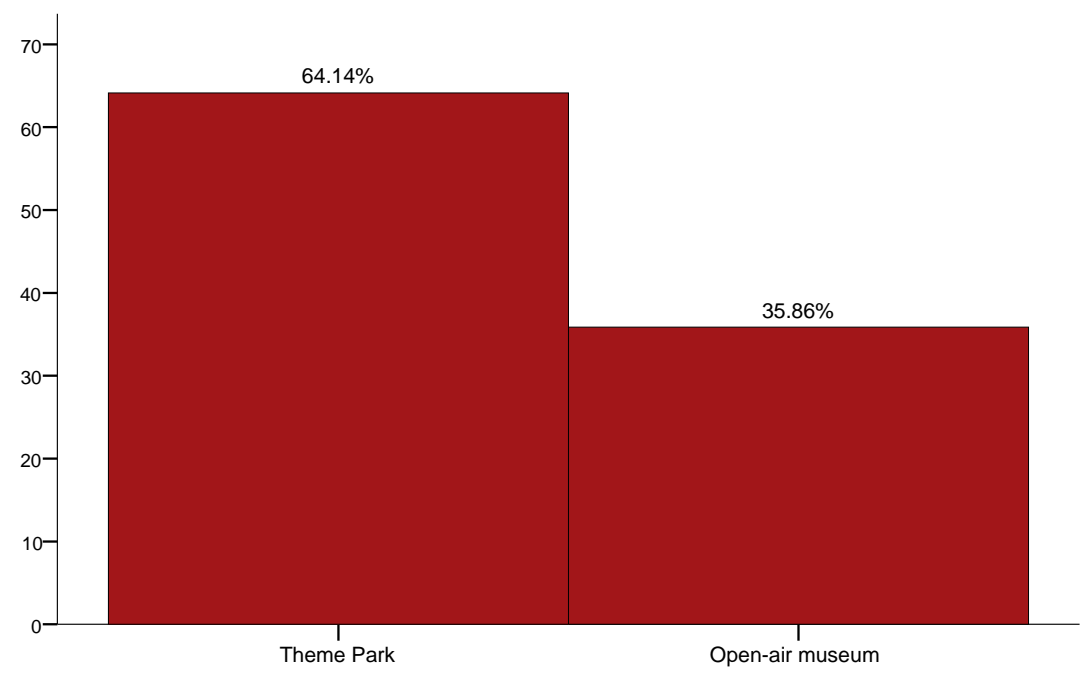

Gambar 3 Anggapan Responden terhadap Taman Mini sebagai Taman Rekreasi atau Museum Terbuka

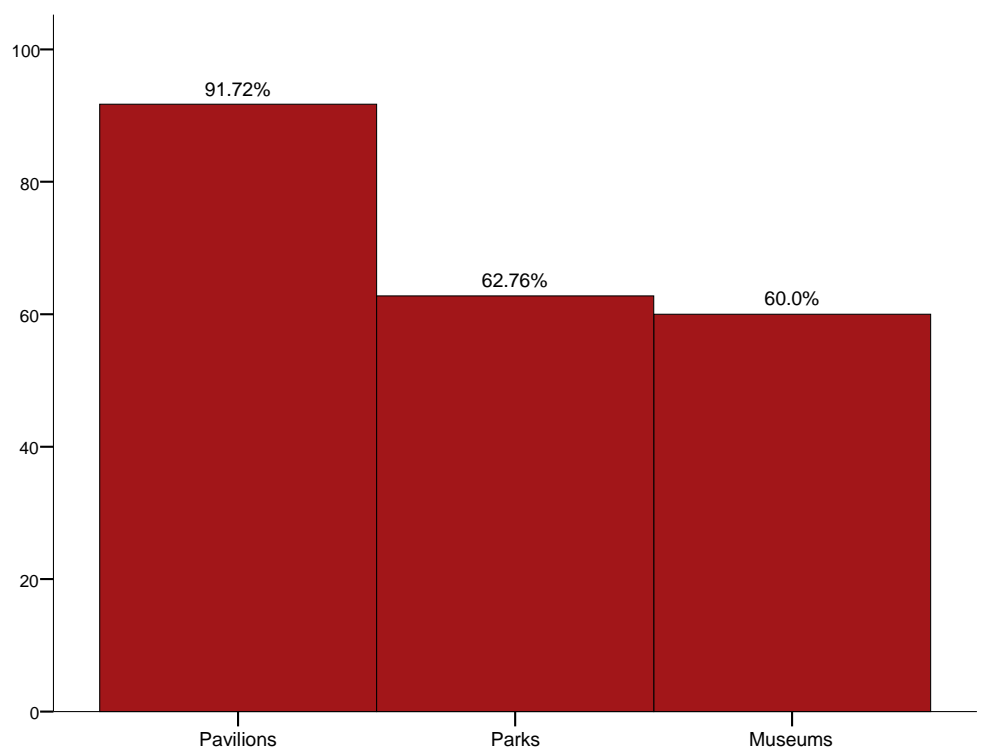

Gambar 4 Grafik Kunjungan Responden pada Fasilitas-fasilitas Taman Mini

Ketika ditanyakan hal-hal apa saja yang mereka lakukan di fasilitas tersebut, sebagaian besar responden (58.65\% pada anjungan daerah dan 53.85\% pada taman) menjawab melihat objek-objek di fasilitas tersebut, hanya sebagian kecil (13.53\% pada anjungan daerah dan $18.68 \%$ pada taman) yang menjawab mereka mengunjungi fasilitas tersebut untuk duduk dan bersantai. Hal ini menunjukkan 
walaupun responden mempunyai orientasi rekreasi, namun mereka tetap tertarik untuk melihat dan memperluas wawasan mereka mengenai keanekaragaman budaya Indonesia dan keadaan alam Indonesia. Karena bila dilihat dari apa yang diharapkan dari kunjungan mereka ke Taman Mini, $62.05 \%$ berharap dapat menambah wawasan mereka mengenai seni dan budaya tradisional Indonesia dan hanya 33.79\% responden berharap kesenangan dan hiburan.

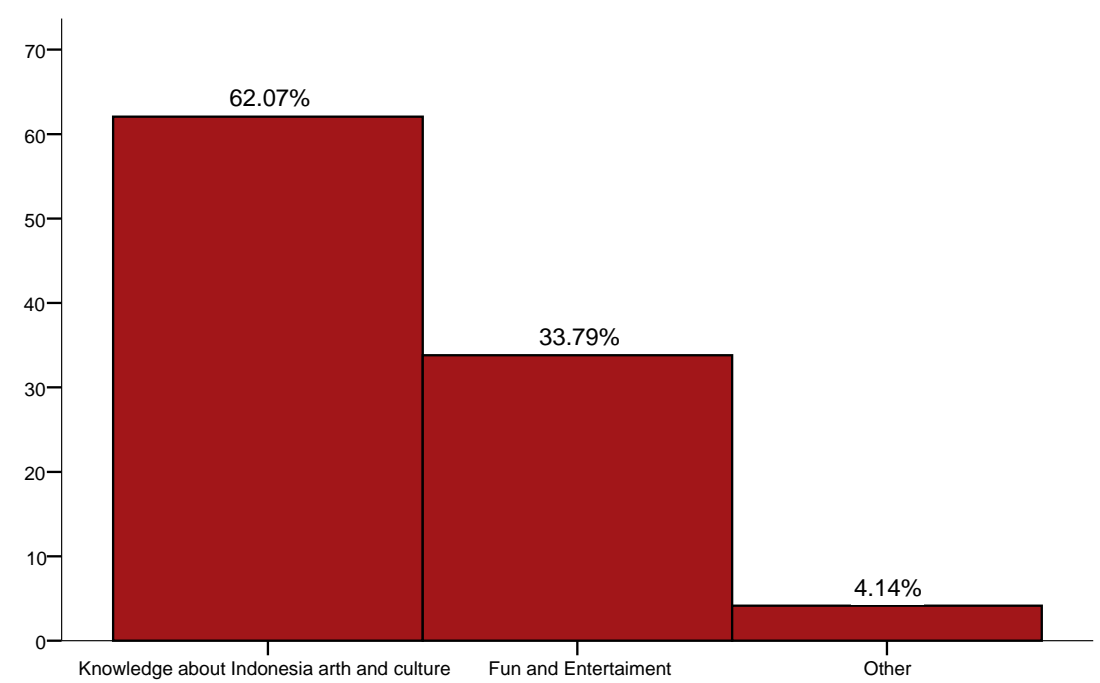

Gambar 5 Grafik Harapan Responden dari Kunjungan ke Taman Mini

Dari hasil ini dapat diajukan argumen, bahwa para pengunjung secara tidak langsung sebenarnya tahu tujuan dari didirikannya Taman Mini, yaitu untuk memperluas wawasan mengenai keanekaragaman budaya Indonesia. Ketika ditanyakan apakah mereka mendapatkan apa yang mereka harapkan dari kunjungan mereka, di atas $60 \%$ responden $(72.2 \%$ pada anjungan daerah, $61.5 \%$ pad a taman, dan $77 \%$ pada museum) menjawab 'ya' bahwa mereka mempelajari sesuatu yang baru di Taman Mini baik di anjungan daerah, taman-taman, maupun museum. Lebih jauh lagi dari survei sikap, lebih dari $90 \%$ responden setuju dan sangat setuju bahwa mereka mempelajari sesuatu yang baru mengenai kebudayaan Indonesia di Taman Mini.

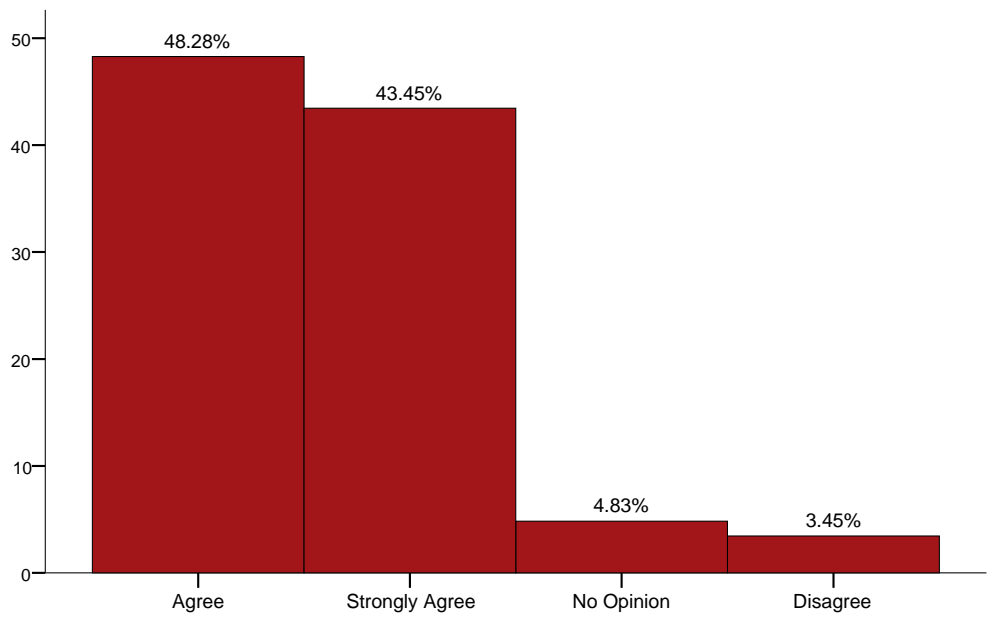

Gambar 6 Sikap Responden terhadap Mempelajari Seni dan Budaya Indonesia 
Dari keseluruhan data ini, dapat disimpulkan bahwa walaupun sebagian besar responden menganggap Taman Mini sebagai tempat rekreasi dan megunjungi Taman Mini dengan tujuan untuk berlibur, mereka tetap mempelajari sesuatu dari kunjungan mereka. Sudah didiskusikan sebelumnya bahwa Taman Mini mengaplikasikan komunikasi massa atau komunikasi satu arah dalam melaksanakan peran edukasi mereka, walaupun disebutkan juga bahwa Taman Mini juga mengadopsi bentuk komunikasi interpersonal melalui program-program edukasi yang terbatas pada kalangan tertentu. Hasil survei juga mendukung hal ini, ketika ditanyakan apakah responden mengetahui mengenai program-program edukasi Taman Mini, 93 (64.1\%) responden menjawab 'tidak' dan 52 (35.9\%) menjawab 'ya' dan dari 35.9\% responden yang menjawab 'ya', hanya 24 responden yang menyatakan pernah berpartisipasi dalam program tersebut. Ini berarti dari keseluruhan responden, hanya 16.6\% responden yang pernah berpartisipasi dalam kegiatan edukasi Taman Mini paling tidak satu kali. Sangat terlihat jelas ini merupakan angka yang kecil sekali. Sedangkan melalui bentuk komunikasi massa tidak dapat dipastikan apa yang sudah dipelajari oleh pengunjung, apakah mereka hanya melihat dan mengenal objek-objek budaya atau mereka benar-benar mempelajari dan mengerti mengenai kebudayaan tradisional Indonesia.

\section{Perbandingan Persepsi}

Masih ada kesalahpahaman mengenai persepsi pendidikan dan hiburan di Taman Mini. Pada satu sisi manajemen Taman Mini setuju bahwa Taman Mini didirikan untuk mengedukasi dan menambah wawasan masyarakat mengenai keanekaragaman budaya Indonesia melalui proses pembelajaran, tetapi di lain sisi, pengunjung Taman Mini menganggap kunjungan mereka adalah kunjungan rekreasiasional. Tujuan ini sangat jelas disebutkan, tetapi manajemen tidak memiliki program yang jelas dan terencana untuk mencapainya. Dengan menghadirkan suasana rekreasi, seharusnya tidak membuat Taman Mini tempat rekreasi dimana masyarakat dapat berpiknik dan bersantai dengan keluarganya sehingga tujuan utama Taman Mini tetaplah edukasi. Pengunjung Taman Mini sebenarnya mengetahui tujuan Taman Mini adalah untuk edukasi, tetapi persepsi mereka mengenai tujuan pendidikan Taman Mini menjadi tidak jelas.

Beberapa alasan tentang hal ini adalah Taman Mini tidak memiliki panduan yang cukup dan terintegrasi mengenai kebijakan pendidikannya; pengunjung tidak dianjurkan dan didorong untuk berpartisipasi dalam program-program edukasi; Taman Mini sudah sangat akrab dan terkenal sebagai fasilitas rekreasi, daripada fasilitas edukasi, seperti terlihat dalam sebuat papan reklame yang bertuliskan 'selamat rekreasi' daripada 'selamat belajar'; dan tidak banyak terdapat area hijau dan tempat rekreasi ataupun ruang terbuka lain di Jakarta. Taman Mini dianggap sebagai area terbesar dan termurah di Jakarta, dimana pengunjung dapat berpiknik dan menghabiskan waktu bersama keluarganya.

Manajemen Taman Mini sendiri sepertinya tidak terlalu khawatir dengan situasi ini dan tidak berusaha untuk membuat suatu perubahan yang berarti. Dari proses pembelajaran yang diterapkan oleh Taman Mini, mungkin baru berhasil dicapai pada tahap pengenalan, dimana pengunjung hanya diperkenalkan kepada keanekaragaman budaya Indonesia. Akan tetapi, pada tahap berikutnya dimana pengunjung mau belajar dan lebih mengapresiasi budaya, sepertinya masih sangat jauh.

Berikutnya dilakukan analisis SWOT untuk mendiskusikan lebih spesifik peran pendidikan di Taman Mini, hal yang membatasi mereka, serta hal yang dapat dilakukan untuk mengembangkan peran edukasi di Taman Mini. 


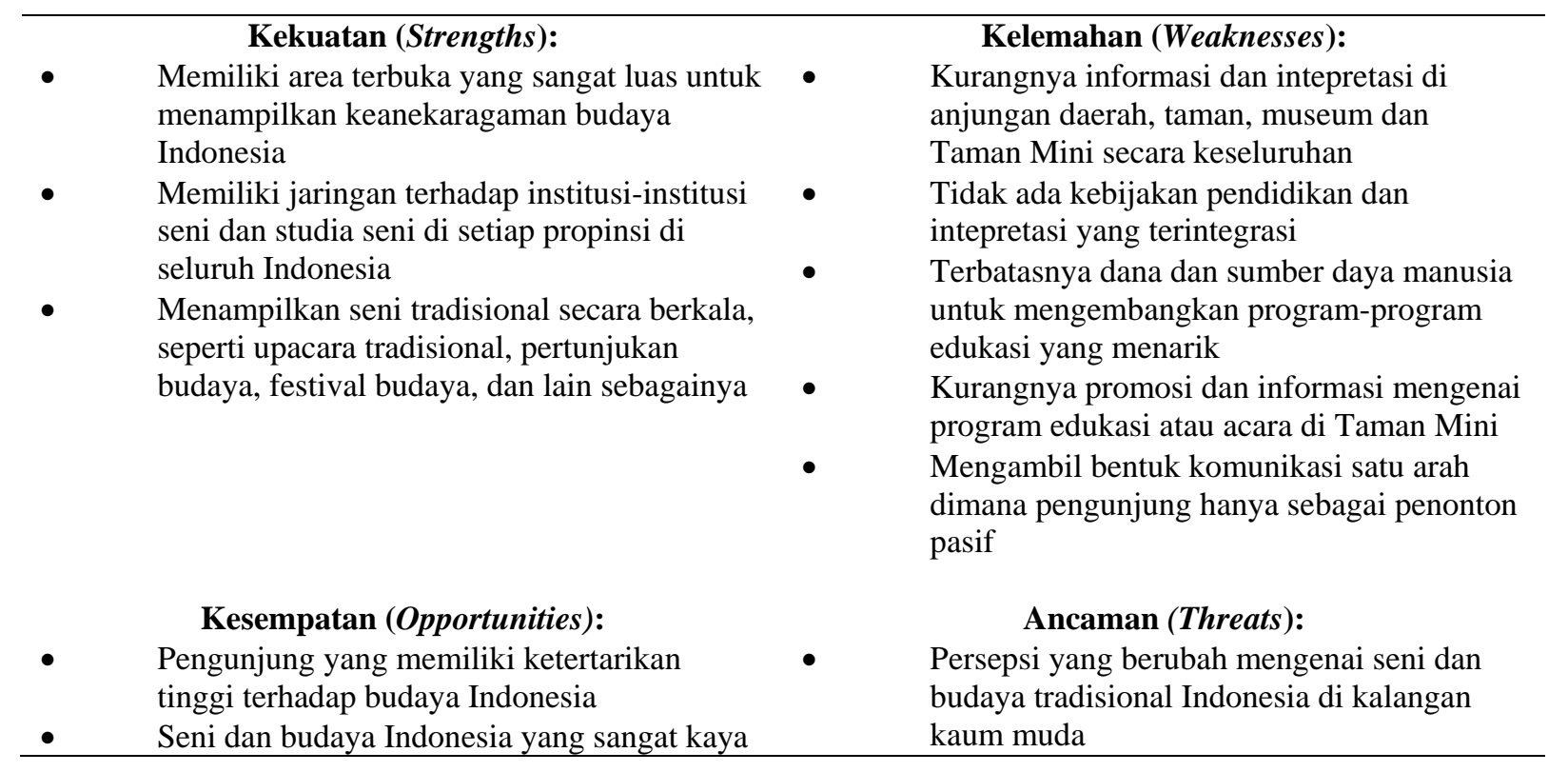

\section{SIMPULAN}

Museum terbuka dapat memiliki berbagai peran dan fungsi. Dengan ruang terbuka, penampilan yang atraktif serta dikombinasikan dengan visual, suara, bau dan rasa, fasilitas ini juga dapat berfungsi sebagai area rekreasi. Di sini, pengunjung tidak hanya melihat objek-objek yang dipamerkan dalam rak-rak kaca berdebu, tetapi juga dapat melihat sejarah yang seakan-akan dihidupkan kembali (living history). Museum terbuka semacam ini yang awalnya hanya memiliki fungsi edukasi, mulai mengkombinasikan pendidikan dan hiburan, disinilah konsep edutainment mulai mengambil alih.

Begitu banyak hal yang ditawarkan oleh fasilitas-fasilitas ini, sehingga terkadang tujuan dan apa yang ditampilkan menjadi tidak sesuai, seperti Taman Mini misalnya. Hasil penelitian menunjukkan bahwa pendiri dan pengunjung memiliki persepsi yang berbeda, dari sudut pandang pendirinya, tujuan dari Taman Mini adalah untuk mendidik bangsa Indonesia serta menyediakan wadah untuk mempelajari keanekaragaman budaya Indonesia melalui suasana rekreasi. Sementara dari sudut pandang pengunjung, Taman Mini lebih baik digunakan sebagai tempat rekreasi, dimana tujuan rekreasi adalah tujuan utama, bersamaan dengan itu pengunjung mempelajari keanekaragaman budaya Indonesia sebagai tujuan berikutnya. Namun karena bentuk komukasi massa yang diambil oleh Taman Mini, tidak dapat dipastikan apa yang sebenarnya dipelajari oleh para pengunjung. Dari yang diharapkan oleh pengunjung terhadap kunjungan mereka, dapat disimpulkan bahwa sebenarnya mereka mengetahui tujuan dari Taman Mini, tetapi karena tidak adanya program-program edukasi yang terintegrasi, kurangnya informasi dan tidak adanya dorongan dari manajemen untuk berpartisipasi pada program-program edukasi, kunjungan mereka menjadi lebih memiliki orientasi rekreasi dibandingkan dengan edukasi. Hal itu ditambah lagi dengan adanya fasilitas-fasilitas baru seperti kolam renang, area outbound anak dan lain-lain yang sama sekali tidak ada kaitannya dengan kebudayaan Indonesia dan sepenuhnya memiliki fungsi rekreasi. Tujuan edukasi Taman Mini menjadi semakin kabur.

Pada saat pertama kali didirikan, Taman Mini sudah memiliki konsep edutainment, dimana pada salah satu misinya jelas tertulis 'menyediakan fasilitas rekreasi yang memiliki nilai-nilai 
edukasi'. Namun manajemen berikutnya, bahkan sampai manajemen saat ini sepertinya enggan untuk mengembangkan konsep ini lebih jauh dengan tidak mendesain serta membuat berbagai program edutainment. Dengan adanya manajemen dua tingkat, setiap manajemen dapat melihat misi Taman Mini dan konsep awal Taman Mini berbeda-beda. Karena inilah konsep edutainment Taman Mini menjadi kabur dan sekarang Taman Mini hanya dikenal sebagai tempat rekreasi. Bila dikaitkan dengan konsep yang ditulis oleh Urry (2002), walaupun mengambil konsep edutainment, Taman Mini bukanlah museum postmodern. Karena di museum-museum postmodern, pengunjung adalah fokus utama. Sedangkan di Taman Mini, pengunjung hanya sebagai pengunjung pasif dan pameran adalah fokus utamanya. Walaupun masih ada beberapa aspek dari Taman Mini yang dapat dianggap sebagai postmodern, hal ini masih terbuka untuk penelitian lebih lanjut.

\section{DAFTAR PUSTAKA}

Boardman, K. (1997). Revisiting Living History: A Business, An Art, A Pleasure, An Education. http://www.alhfam.org/whitepapers/alfham.revisit.html.

Clark, M., et.al. (1998). Research and Writing Deissertations in Hospitality and Tourism. London: Thomson Business Press.

Easterby-smith, M. Thorpe, R. and Lowe, A. (1991). Management Research: An Introduction. London: Sage Publications, Inc.

Hendry, J. (2000). The Orient Strike Back: A Global Views of Cultural Displays. Oxford: Berg.

Hitchcock, M. (1998). Tourism, Taman Mini and National Identity. Indonesia and the Malay World. Vol. 26, No. 75, h. 124-135+

Hitchcock, M. S., N. \& Siu, Kung Chung. (1997). The South-east Asian'Living Museum' and its Antecedents. dalam S. Abram, dkk (eds.) Tourists and Tourism: Identifying with People and Places, Oxford: Berg.

Hooper-Greenhill, E. (1994). Museum Education dalam E. Hopper-Greenhill (ed.). The Educational Role of the Museum, London: Routledge.

Hussey, J., and Hussy, R. (1997). Business Research: A practical guide for undergraduate and postgraduate students. London: Macmillan.

Mason, J. (1994). Linking qualitative and quantitative data analysis. in A. Bryman and R. G. Burgess (eds.) Analyzing Qualitative Data. London: Routledge.

Stanley, N. (1998). Being Ourselves for You: the Global Display of Cultures. London: Middlesex University Press.

Taman Mini Indonesia Indah Guidebook. (1996). Pesona Wisata Budaya Taman Mini Indonesia Indah. Jakarta: Taman Mini Indonesia Indah.

Taman Mini Indonesia Indah Official Website, http://www.tamanmini.com

White, R. (2003). That's Edutainment. Kansas City: White Hutchinson Leisure and Learning Groups. www.whitehutchinson.com/leisure/articles/edutainment/shtml. 